\title{
A Gram-Negative False-Negative: Normal Procalcitonin Level in a Patient with Multiple Klebsiella Pneumoniae Intra-Abdominal Abscesses: A Case Report and Literature Review
}

\author{
Mario D. Caldararo, MD
}

\section{INTRODUCTION}

Despite over 3,000 peer-reviewed articles on procalcitonin (PCT) since 2004, guidance on its usage is sparse. ${ }^{1}$ An analysis of more than 500 United States hospitals in the Premier Healthcare Database found large differences in utilization exist across regions (115 PCT encounters per 10,000 patients in the Northeast vs. 408 to 576 in other regions) and teaching vs. non-teaching hospitals (345 vs. 530 PCT encounters per 10,000 patients, respectively). ${ }^{2}$ The purpose of this work is to describe a case that exemplifies the caveats in PCT interpretation and to summarize the current knowledge of the clinical utilization of PCT.

\section{CASE PRESENTATION}

A 78-year-old male with a history of hypothyroidism, Lewy body dementia and long-term central venous access for nutritional infusions was admitted for the radiologically-guided placement of drains into newly found intra-abdominal abscesses seen at an outside hospital. On presentation he was nonverbal. Family reported the abscesses were found incidentally; the patient had not displayed any different behaviors or symptoms. He had begun receiving ertapenem for seven days prior to admission. His home medications included anastrazole, Westhroid ${ }^{T M}$ (a pork thyroid preparation), and supplemental nutrients including bearberry leaf extract, CoQ-10, cholecalciferol, boron, huperzine serrate, Endefen ${ }^{\mathrm{TM}}$, L-carnitine, niacin, DHEA, and taurine.

On admission, his vitals included temperature $96.2^{\circ} \mathrm{F}$, heart rate 80 beats per minute, blood pressure 121/55 $\mathrm{mmHg}$, respiratory rate 18 breaths per minute, and $\mathrm{SpO} 2$ of $97 \%$ on room air. Physical exam revealed a frail and cachectic, but non-toxic appearing elderly man with diffuse abdominal tenderness. Laboratory studies were notable for white blood cell count $20.6 \times 10^{9} / \mathrm{L}$ [4,000-11,000 x 10\%/L] with $87.0 \%$ neutrophils [40-80\%] on automated differential (manual differential not performed for band forms), hemoglobin $9.2 \mathrm{~g} / \mathrm{dL}$ [13.5-16.5 g/dL], platelets $422 \times 10^{9} / \mathrm{L}\left[150-450 \times 10^{9} / \mathrm{L}\right]$, sodium 135 mmol/L [135-145 mmol/L], bicarbonate 24 $\mathrm{mmol} / \mathrm{L}$ [22-32 mmol/L], normal anion gap, blood urea nitrogen $11 \mathrm{mg} / \mathrm{dL}$ [7-20 mg/dL], creatinine $1.0 \mathrm{mg} / \mathrm{dL}$ [0.6-1.2], normal liver enzymes and coagulation studies. C-reactive protein was $5.50 \mathrm{mg} / \mathrm{dL}$. Erythrocyte sedimentation rate was $80 \mathrm{~mm} / \mathrm{hr}$. TSH was $43.15 \mathrm{\mu lU} /$ $\mathrm{mL}$ with a low T4 of $0.4 \mathrm{ng} / \mathrm{dL}$. Procalcitonin was 0.07 $\mathrm{ng} / \mathrm{mL}$ (upper limit of normal $0.09 \mathrm{ng} / \mathrm{mL}$ ).

CT of the abdomen and pelvis showed four fluid collections concerning for abscesses: a left lateral abdominal wall collection measuring $13.7 \times 11.6 \times 3.0$ $\mathrm{cm}$ that contained multiple foci of air, a left lower quadrant collection measuring $8.1 \times 3.6 \times 2.8 \mathrm{~cm}$, a prevesical collection measuring $7.4 \times 6.8 \times 1.3 \mathrm{~cm}$, and a right lower quadrant collection anteriorly measuring $7.8 \times 0.9 \times 0.6 \mathrm{~cm}$. On hospital day two, interventional radiology placed drainage catheters into the left lateral and left lower quadrant collections. Cultures grew moderate to heavy growth multi-drug resistant Klebsiella pneumoniae (Figure 1).

The patient remained stable and white blood cell count trended down. He continued to receive ertapenem. He was discharged on day three with plans to follow-up with interventional radiology for drain removal.

\begin{tabular}{|c|c|c|c|c|c|}
\hline Amikacin & $\begin{array}{r}\quad=4 \\
\mathrm{mcg} / \mathrm{mL}\end{array}$ & Susceptible & Ertapenem & $\begin{array}{l}<=0.12 \mathrm{~s} \\
\mathrm{mcg} / \mathrm{mL}\end{array}$ & Susceptible \\
\hline $\begin{array}{l}\text { Amoxicillin + } \\
\text { Clavulanate }\end{array}$ & $\begin{array}{r}8 / 4 \\
\mathrm{mcg} / \mathrm{mL}\end{array}$ & Susceptible & Gentamicin & $\begin{array}{r}>8 \\
\mathrm{mcg} / \mathrm{mL}\end{array}$ & Resistant \\
\hline $\begin{array}{l}\text { Ampicillin + } \\
\text { Sulbactam }\end{array}$ & $\begin{array}{r}>16 / 8 \\
\mathrm{mcg} / \mathrm{mL}\end{array}$ & Resistant & Levofloxacin & $\begin{array}{r}>4 \\
\mathrm{mcg} / \mathrm{mL}\end{array}$ & Resistant \\
\hline Aztreonam & $\begin{array}{r}>16 \\
\mathrm{mcg} / \mathrm{mL}\end{array}$ & Resistant & Meropenem & $\begin{array}{l}<=0.125 \\
\mathrm{mcg} / \mathrm{mL}\end{array}$ & Susceptible \\
\hline Cefepime & $\begin{array}{r}16 \\
\mathrm{mcg} / \mathrm{mL}\end{array}$ & Resistant & $\begin{array}{l}\text { Piperacillin + } \\
\text { Tazobactam }\end{array}$ & $\begin{array}{r}8 / 4 \\
\mathrm{mcg} / \mathrm{mL}\end{array}$ & Susceptible \\
\hline Cefoxitin & $\begin{array}{r}>16 \\
\mathrm{mcg} / \mathrm{mL}\end{array}$ & Resistant & Tetracycline & $\begin{array}{r}8 \\
\mathrm{mcg} / \mathrm{mL}\end{array}$ & Intermediate \\
\hline Ceftriaxone & $\begin{array}{r}>32 \\
\mathrm{mcg} / \mathrm{mL}\end{array}$ & Resistant & Tobramycin & $\begin{array}{r}8 \\
\mathrm{mcg} / \mathrm{mL}\end{array}$ & Intermediate \\
\hline Ciprofloxacin & $\begin{array}{r}>2 \\
\mathrm{mcg} / \mathrm{mL}\end{array}$ & Resistant & $\begin{array}{l}\text { Trimethoprim + } \\
\text { Sulfamethoxazole }\end{array}$ & $\begin{array}{r}>2 / 38 \\
\mathrm{mcg} / \mathrm{mL}\end{array}$ & Resistant \\
\hline
\end{tabular}

Figure 1. Antibiotic sensitivities for the Klebsiella pneumonia isolate aspirated from the patient's intra-abdominal abscesses. 


\section{REVIEW OF LITERATURE}

Under normal physiologic conditions, PCT is a prohormone produced in the thyroid gland that is further processed to yield calcitonin, one of the primary hormones involved in calcium homeostasis. During bacterial infections, other tissues begin expressing PCT without processing it into calcitonin, or having detectable effects on calcium homeostasis...4 While this finding has raised considerable in the usage of $\mathrm{PCT}$ as a specific marker of bacterial infections, the biological function of extra-thyroidal PCT remains unknown. ${ }^{5}$

The Food and Drug Administration (FDA) has approved the use of PCT assays as a guide for beginning and discontinuing antibiotic therapy in suspected lower respiratory tract infections. ${ }^{1}$ The FDA indication was informed in part by a Cochrane review that found PCT-guided antibiotic therapy in acute respiratory tract infections reduced antibiotic usage and mortality risk. ${ }^{6}$ The FDA also approved using PCT to guide de-escalation of antibiotics during sepsis.

Although PCT-guided antibiotic prescribing algorithms are intended to decrease the use and duration of antibiotics, data are mixed. Huang et al note two main criticisms of existing clinical trials: that they were conducted in Europe where antibiotic prescribing practices may differ from the United States, and that physicians could override the PCT-guided algorithms. ${ }^{7}$ To address these criticisms, their group conducted a large trial in the United States: finding that PCT-guided algorithms did not change the number of antibiotic-days patients received.?

There are only a few Infectious Disease Society of America (IDSA) guidelines in which PCT appears. A 2016 IDSA guideline on antibiotic stewardship contains a weak recommendation for serial PCT measurements for guidance of antibiotic de-escalation in adult ICU patients. ${ }^{8}$ A 2017 IDSA guideline contains weak recommendations for using serum PCT to differentiate between cerebrospinal fluid abnormalities due to surgery or intracranial hemorrhage vs. bacterial infection. The weak recommendation also extends to healthcare-associated bacterial ventriculitis and meningitis, which are based on studies reporting serum PCT having 100\% specificity for bacterial meningitis. ${ }^{9-11}$ A separate 2016 IDSA guideline on hospital-acquired pneumonia recommends against the usage of PCT to initiate antibiotics. ${ }^{12}$ IDSA 2007 community-acquired pneumonia guidelines do not make recommendations for or against usage of PCT.

Data for the utility of PCT as it pertains to localized infections and abscesses are limited. A review on PCT in localized infections by Saeed. Ahmad, and Dryden reported two small ( $<100$ patients) studies showing promise for using PCT to determine the need for antibiotics in wound infection.13 The studies, however, suffered major limitations including heterogeneous samples in one and a lack of control group in the other. PCT for diagnostic aide in diabetic foot infection had mixed data with positive results appearing with low thresholds (0.2-0.5 ng/mL). Data do not support usage of PCT in diagnosis of septic arthritis and was not found to be a reliable marker over several small studies in osteomyelitis without sepsis.

Soderquist et al found patients with non-bacteremic septic arthritis and crystal-induced arthritides had similar PCT levels. ${ }^{14}$ Hammer et al found lower PCT levels in localized infections when trying to discern between infection and acute rejection in transplant recipients; however, abscesses were not specified as one of the localized infections studied. ${ }^{15}$ Gendrel et al found lower, but still elevated, PCT levels in pediatric patients with localized vs. generalized infections. ${ }^{16}$ In contrast, an abstract published in 2013 reported PCT to be a specific marker for intra-abdominal abscesses in Crohn's disease with a higher mean serum PCT compared to patients without abscesses, however, ranges were not specified. ${ }^{17}$ Another study conducted in 10 patients on extracorporeal oxygen therapy-with one of them having an abscess-concluded PCT performed well as an indicator of infection. 18

\section{CASE DISCUSSION}

The focus of this report is the normal-range PCT level in the context of confirmed intra-abdominal bacterial infection with evidence of a systemic response (leukocytosis, hypothermia, elevated inflammatory markers) and organ damage (acute kidney injury).

The case raises the question of the effect of hypothyroidism on PCT measurements, which is not well studied. One study involving 24 patients who had received total thyroidectomy for medullary thyroid carcinoma showed that PCT was not decreased; however, fourteen patients were found to have residual thyroid tissue on ultrasound, eight had regional recurrence, and two had distant metastases..$^{19}$ In a study involving patients with Hashimoto's thyroiditis, those with Hashimoto's had higher mean PCT levels than controls, and PCT was positively correlated with anti-thyroglobulin and anti-thyroid peroxidase levels. ${ }^{20}$ Based on these data, there is either a paradoxical effect on PCT levels or no effect at all, which is in accordance with the understanding that PCT in infected states is extra-thyroidal in nature. ${ }^{3.4}$

Another possible explanation for the false-negative is antibiotic pre-treatment. Administration of antibiotics prior to obtaining an initial PCT has been shown to lead to lower PCT values. ${ }^{21}$ This patient was receiving ertapenem for seven days prior to his admission. It is presumable that if PCT is intended to indicate a systemic response to an infection as the literature so far shows, 
then values should still be elevated if the microbial burden has not been decreased enough so as to temper that systemic response (e.g. poor source control, inadequate duration of treatment, etc.).

An additional, yet equally important consideration, is that this patient may not have been septic. At first, this seemed to be unlikely given the magnitude of the Gram-negative microbial burden evidenced in the patient's abdomen. Such anatomically disparate foci of infection (left abdominal wall, left lower quadrant, right lower quadrant, pre-vescicular) suggests there may have been a recent seeding event in the context of long-term indwelling central venous access. Given the highly virulent nature of Klebsiella pneumoniae, it should have produced a robust and clinically obvious systemic response. ${ }^{22}$ However, by the current "Sepsis-3" diagnostic criteria utilizing the sequential organ failure assessment (SOFA) score, the patient may have not met criteria. ${ }^{23}$ Although he was diagnosed with acute kidney injury based on a creatinine of $1.0 \mathrm{mg} / \mathrm{dL}$ increased from a previously known $0.7 \mathrm{mg} /$ $\mathrm{dL}$, it did not meet the SOFA criterion of $1.2 \mathrm{mg} / \mathrm{dL}$. Clinically, he appeared to be severely malnourished and wasted in appearance, so a prior creatinine of $0.7 \mathrm{mg} / \mathrm{dL}$ documented some weeks before the current admission may still have been above his true baseline; there were no other values documented. As such, he was considered to have a true acute kidney injury, though it may not have been due to sepsis. Determination of his baseline mental status was confounded by his underlying Lewy body dementia, making a Glasgow coma score SOFA criterion impossible to reliably obtain. Significantly, he had none of the typical hemodynamic changes classically associated with sepsis. Finally, despite the perilous locations of the patient's abscesses, they may have been walled off to the extent that they were effectively localized.

A final consideration is the patient's many herbal supplements as possible confounders. Herbal extracts often contain numerous compounds in varying amounts that may or may not be relevant to a given clinical scenario. As an example, one study found that ursolic acid, one of the compounds in bearberry leaf extract, was able to ameliorate acute kidney injury associated with sepsis in mice. ${ }^{24} \mathrm{~A}$ thorough review of the potential impact of each of these supplements on the patient's clinical presentation is beyond the scope of this work.

False-positive PCT occurrences greatly outnumber those of false-negatives. Christ-Crain and Muller have compiled a list of common clinical scenarios. ${ }^{25}$ This list is adapted from their article and presented in Table 1. It should be noted that regarding the elimination of $\mathrm{PCT}$, the renal system does not appear to play a significant role, therefore, acute kidney injury is not thought to produce false-positives. ${ }^{26,27}$ Table 2 provides a summary of test characteristics found across some of the larger studies performed. Performance usually varies with the threshold value studied.

\begin{tabular}{|c|c|}
\hline False-positives & False-negatives \\
\hline $\begin{array}{l}\text { Newborns (physiologically) during } \\
\text { first days of life }\end{array}$ & Early course of infections \\
\hline $\begin{array}{l}\text { Acute respiratory distress } \\
\text { syndrome }\end{array}$ & Localized infections \\
\hline $\begin{array}{l}\text { Acute attacks of plasmodium } \\
\text { falciparum malaria }\end{array}$ & Subactue endocarditis \\
\hline $\begin{array}{l}\text { Systemic fungal infections (e.g. } \\
\text { candidiasis, aspergillosis) }\end{array}$ & \\
\hline Severe mechanical trauma & \\
\hline Following surgical trauma & \\
\hline $\begin{array}{l}\text { Administration of monoclonal or } \\
\text { polyclonal anti-thymocyte globulin } \\
\text { in the treatment of acute rejection } \\
\text { after transplantation }\end{array}$ & \\
\hline Chemical pneumonitis & \\
\hline Severe burns and heat strokes & \\
\hline $\begin{array}{l}\text { Patients with medullary thyroid } \\
\text { cancer, small cell cancer of the } \\
\text { lung, carcinoid, tumours with } \\
\text { paraneoplastic hormone production }\end{array}$ & \\
\hline $\begin{array}{l}\text { Inflammation associated with } \\
\text { "cytokine storms", eg IL } \beta \text {, in } \\
\text { familial Mediterranean fever, } \\
\text { therapeutic infusions of TNF } \alpha \text { for } \\
\text { melanoma }\end{array}$ & \\
\hline
\end{tabular}

Table 1. Clinical scenarios that may produce false-positive or falsenegative PCT values. Adapted from Christ-Crain and Muller, 2005.25

\begin{tabular}{l|r|r|r|l|l} 
Condition & PCT threshold (ng/mL) & Sensitivity $(\%)$ & Specificity (\%) & Study type & Citation \\
\hline $\begin{array}{l}\text { Mixed bacterial } \\
\text { pneumonia versus } \\
\text { H1N1 flu }\end{array}$ & $>1.5$ & 56 & 844 & $\begin{array}{l}\text { Retrospective } \\
\text { single center }\end{array}$ & $\begin{array}{l}\text { Ahn et al. } \\
2011\end{array}$ \\
\hline $\begin{array}{l}\text { Bacterial vs. non- } \\
\text { infective } \\
\text { inflammation }\end{array}$ & $0.5-6.1$ & 85, pooled & 83, pooled & Meta analysis & $\begin{array}{l}\text { Simon et al. } \\
2004\end{array}$ \\
\hline $\begin{array}{l}\text { Bacterial vs. viral } \\
\text { Bacteremic vs. non- } \\
\text { bacteremic fever }\end{array}$ & $0.5-6.1$ & 82, pooled & 88, pooled & Meta analysis & $\begin{array}{l}\text { Simon et al. } \\
2004\end{array}$ \\
\hline $\begin{array}{l}\text { Bacterial vs. non- } \\
\text { infective } \\
\text { inflammation }\end{array}$ & $>0.4$ & 95.2 & 57.4 & $\begin{array}{l}\text { Prospective two } \\
\text { center cohort }\end{array}$ & $\begin{array}{l}\text { Chirouze et al. } \\
2002\end{array}$ \\
\hline \begin{tabular}{l} 
Infection vs. SIRS \\
\hline Bacterial vs. viral \\
pneumonia
\end{tabular} & $>0.5$ & 65 & 96 & $\begin{array}{l}\text { Prospective single } \\
\text { center cohort }\end{array}$ & $\begin{array}{l}\text { Delavaux et } \\
\text { al. 2003 }\end{array}$ \\
\hline
\end{tabular}

Table 2. Selected published analyses of PCT sensitivity and specificity. $3.28-32$

\section{CONCLUSION}

Serum PCT can be a useful addition to the diagnostic armamentarium in the evaluation of bacterial infection. Similar to other biomarkers, it should not be solely relied on or supplant clinical judgement. While false-positive scenarios are more common, careful consideration must be given to possible false-negative scenarios as this case demonstrates. Testing may prove useful in cases of clinical uncertainty and a PCT-guided algorithm may be a beneficial addition to an established antimicrobial stewardship program 


\section{CURRENT FDA INDICATIONS FOR TEST USAGE}

The current FDA recommendation for usage of the test in lower respiratory tract infections is strong discouragement of antibiotics for PCT levels less than $0.1 \mathrm{ng} / \mathrm{mL}$, discouragement for 0.1 to $0.25 \mathrm{ng} / \mathrm{mL}$, recommendation for 0.25 to $0.5 \mathrm{ng} / \mathrm{mL}$, and strong recommendation for levels greater than $0.5 \mathrm{ng} / \mathrm{mL}$. Additionally, the current FDA recommendation for usage of the test in sepsis is discontinuation recommended if $\mathrm{PCT}$ is less than or equal to 0.5 $\mathrm{ng} / \mathrm{mL}$ or if the PCT levels have decreased by greater than $80 \%$ from peak value. ${ }^{1}$

\section{REFERENCES}

1. Food and Drug Administration. Discussion and recommendations for the application of procalcitonin to the evaluation and management of suspected lower respiratory tract infections and sepsis. FDA Executive Summary. 2016. Accessed July 25, 2018

2. Kadri S, Rhee C, Cao Z, Robinson SB, Lipkin CB, Bozzette S, et al. The epidemiology of procalcitonin use in united states hospitals. Open Forum Infectious Diseases. 2016:3(suppl_1): 229.

3. Assicot M, Gendrel D, Carsin H, Raymond J, Guilbaud J, Bohuon C. High serum procalcitonin concentrations in patients with sepsis and infection. Lancet 1993; 341:515-518.

4. Müller B, White JC, Nylén ES, Snider RH, Becker KL, Habener JF. Ubiquitous expression of the calcitonin-I gene in multiple tissues in response to sepsis. J Clin Endocrinol Metab 2001; 86: 396-404.

5. Jin M, Khan Al. Procalcitonin: uses in the clinical laboratory for the diagnosis of sepsis. Laboratory Medicine. 2010; 41(3): 173-7.

6. Schuetz P, Wirz Y, Sager R, Christ-Crain M, Stolz D, Tamm M, et al. Procalcitonin to initiate or discontinue antibiotics in acute respiratory tract infections. The Cochrane database of systematic reviews. 2017; 10: Cd007498.

7. Huang DT, Yealy DM, Filbin MR, Brown AM, Chang C-CH, Doi Y, et al. Procalcitonin-guided use of antibiotics for lower respiratory tract infection. New England Journal of Medicine. 2018; 379(3): 236-49.

8. Barlam TF, Cosgrove SE, Abbo LM, MacDougall C, Schuetz AN, Septimus EJ, et al. Implementing an antibiotic stewardship program: guidelines by the infectious diseases society of america and the society for healthcare epidemiology of america. Clinical infectious diseases : an official publication of the Infectious Diseases Society of America. 2016; 62(10): e51-77.

9. Tunkel AR, Hasbun R, Bhimraj A, Byers K, Kaplan SL, Scheld WM, et al. 2017 infectious diseases society of america's clinical practice guidelines for healthcareassociated ventriculitis and meningitis. Clinical Infectious Diseases. 2017; 64(6): e34-e65.

10. Schwarz S, Bertram M, Schwab S, Andrassy K, Hacke W. Serum procalcitonin levels in bacterial and abacterial meningitis. Crit Care Med 2000; 28: 1828 - 32.

11. Berger C, Schwarz S, Schaebitz WR, Aschoff A, Schwab S. Serum procalcitonin in cerebral ventriculitis. Crit Care Med 2002; 30: 1778 - 81.

12. Kalil AC, Metersky ML, Klompas M, Muscedere J, Sweeney DA, Palmer LB, et al. Management of adults with hospital-acquired and ventilator-associated pneumonia: 2016 Clinical Practice Guidelines by the Infectious Diseases Society of America and the american thoracic society. Clinical infectious diseases: an official publication of the Infectious Diseases Society of America. 2016;63(5):e61e111.

13. Saeed K, Ahmad N, Dryden M. The value of procalcitonin measurement in localized skin and skin structure infection, diabetic foot infections, septic arthritis and osteomyelitis. Expert review of molecular diagnostics. 2014; 14(1): 47-54

14. Soderquist B, Jones I, Fredlund H, Vikerfors T. Bacterial or crystal-associated arthritis? discriminating ability of serum inflammatory markers. Scandinavian journal of infectious diseases. 1998; 30(6): 591-6.
15. Hammer S, Meisner F, Dirschedl P, Hobel G, Fraunberger P, Meiser B, et al. Procalcitonin: a new marker for diagnosis of acute rejection and bacterial infection in patients after heart and lung transplantation. Transplant immunology. 1998; 6(4): 235-41.

16. Gendrel D, Raymond J, Coste J, et al. Comparison of procalcitonin with C-reactive protein, interleukin 6 and interferonalpha for differentiation of bacterial vs. viral infections. Pediatr Infect Dis J 1999; 18: 875-81.

17. Hu D, Ren J, Liu S, Yan D, Wang G, Gu G, et al. Diagnostic value of serum procalcitonin in detecting intra-abdominal abscess in patients with crohn's disease. Journal of the American College of Surgeons. 2013; 217(3): S33.

18. Tanaka D, Pitcher HT, Cavarocchi NC, Diehl JT, Hirose H. Can procalcitonin differentiate infection from systemic inflammatory reaction in patients on extracorporeal membrane oxygenation? The Journal of heart and lung transplantation : the official publication of the International Society for Heart Transplantation. 2014; 33(11): 1186-8.

19. Bolko P, Manuszewska-Jopek E, Michalek K, Wasko R, Jaskula M, Sowinski J. Efficacy of procalcitonin measurement in patients after total thyroidectomy due to medullary thyroid carcinoma. Archivum immunologiae et therapiae experimentalis. 2003; 51(6): 415-9.

20. 20. Oncul A, Ates I, Arikan MF, Yilmaz N, Topcuoglu C, Yilmaz FM, et al. The relationship between procalcitonin and thyroid autoantibodies in patients with autoimmune thyroiditis. Journal of clinical laboratory analysis. 2017; 31(6).

21. Kruger S, Ewig S, Kunde J, Hartmann O, Marre R, Suttorp N, et al. Assessment of inflammatory markers in patients with community-acquired pneumonia-influence of antimicrobial pre-treatment: results from the German competence network CAPNETZ. Clinica chimica acta; international journal of clinical chemistry. 2010; 411(23-24): 1929-34.

22. Clegg S, Murphy CN. Epidemiology and Virulence of Klebsiella pneumoniae. Microbiology spectrum. 2016; 4(1).

23. Seymour CW, Liu VX, Iwashyna TJ, Brunkhorst FM, Rea TD, Scherag A, et al. Assessment of clinical criteria for sepsis: for the third international consensus definitions for sepsis and septic shock (sepsis-3). Jama. 2016; 315(8): 762-74.

24. Zhang, Z., Zhang, H., Chen, R., \& Wang, Z. Oral supplementation with ursolic acid ameliorates sepsis-induced acute kidney injury in a mouse model by inhibiting oxidative stress and inflammatory responses. Molecular medicine reports. 2018; 17(5), 7142-7148.

25. Christ-Crain M, Muller B. Procalcitonin in bacterial infections--hype, hope, more or less? Swiss medical weekly. 2005; 135(31-32): 451-60.

26. Meisner M, Schmidt J, Huttner $H$, Tschaikowsky K. The natural elimination rate of procalcitonin in patients with normal and impaired renal function. Intensive care medicine. 2000; 26 Suppl 2: S212-6

27. Rodriguez A, Reyes LF, Monclou J, Suberviola B, Bodi M, Sirgo G, et al. Relationship between acute kidney injury and serum procalcitonin (PCT) concentration in critically ill patients with influenza infection. Medicina intensiva. 2018; 42(7): 399-408.

28. Ahn S, Kim WY, Kim SH, Hong S, Lim CM, Koh Y, et al. Role of procalcitonin and C-reactive protein in differentiation of mixed bacterial infection from 2009 H1N1 viral pneumonia. Influenza and other respiratory viruses. 2011; 5(6): 398-403.

29. Simon L, Gauvin F, Amre DK, Saint-Louis P, Lacroix J. Serum procalcitonin and c-reactive protein levels as markers of bacterial infection: a systematic review and meta-analysis. Clinical infectious diseases: an official publication of the Infectious Diseases Society of America. 2004; 39(2): 206-17.

30. Chirouze C, Schuhmacher H, Rabaud C, Gil H, Khayat N, Estavoyer JM, et al. Low serum procalcitonin level accurately predicts the absence of bacteremia in adult patients with acute fever. Clinical infectious diseases: an official publication of the Infectious Diseases Society of America. 2002; 35(2): 156-61

31. Delevaux I, Andre M, Colombier M, Albuisson E, Meylheuc F, Begue RJ, et al. Can procalcitonin measurement help in differentiating between bacterial infection and other kinds of inflammatory processes? Annals of the rheumatic diseases. 2003; 62(4): 337-40.

32. Uzzan B, Cohen R, Nicolas P, Cucherat M, Perret GY. Procalcitonin as a diagnostic test for sepsis in critically ill adults and after surgery or trauma: a systematic review and meta-analysis. Critical care medicine. 2006; 34(7): 1996-2003. 